\title{
Hidrogeologia costeira: aspectos comparativos em área de sedimento recente do Quaternário Holoceno - litoral do Paraná
}

\author{
Coastal hydrogeology: comparative issues in area of recent Quaternary sediment Holocene - Paraná \\ coast \\ ROGÉRIO TADEU DE SOUZA*, ERNANI FRANCISCO DA ROSA FILHO**, THIAGO ELIAS RAMOS BONIS SILVA***, \\ EDUARDO CHEMAS HINDI**, HUMBERTO COELHO DE MELO**** \\ * Mestre em Hidrogeologia, UFPR, (rts.souza@ig.com.br) \\ ** Laboratório de Pesquisas Hidrogeológicas-LPH, DEGEOL-UFPR \\ *** Hidrogeólogo MDGEO Serviços de Hidrogeologia Ltda \\ **** Engenheiro Civil, especialista em gestão de projetos
}

\begin{abstract}
Resumo
A hidrogeologia costeira possui características bastante peculiares, tanto sob o ponto de vista quantitativo quanto qualitativo. Neste estudo, são apresentados os resultados comparativos entre dois estudos realizados em duas áreas da costa litorânea do Paraná. Uma área está localizada na Ilha dos Valadares e, outra em uma área localizada em Pontal do Sul. Os resultados comprovam que mesmo estando na mesma feição geológica e próximas, aproximadamente $17 \mathrm{~km}$, os resultados hidrogeológicos apresentam consideráveis variações. Na Ilha dos Valadares, o efeito da maré no nível d'água subterrâneo influência a qualidade da água e fluxo subterrâneo o que não é observado na área em Pontal do Sul. A condutividade hidráulica tem variação da ordem de $102 \mathrm{~cm} / \mathrm{s}$. A condutividade elétrica em Pontal do Sul é consideravelmente mais baixa que na llha dos Valadares, indicando um aqüifero livre de origem continental e sem influência de maré. A recarga em ambas as áreas estão essencialmente relacionadas a pluviosidade porém, a descarga na Ilha dos Valadares está ligada aos poços que servem a população na forma de abastecimento enquanto que em Pontal do Sul a descarga está fortemente direcionada para o rio Perequê e sua área de mangue e em uma faixa muito estreita, próximo a praia, para o mar.
\end{abstract}

Palavras-chave: hidrogeologia, Pontal do Sul, Ilha dos Valadares

\begin{abstract}
The coastal hydrogeology has peculiar characteristics, both in quantitative and qualitative points of view. In this study, we present the comparative results between two studies in two areas of the coastline of Paraná. One area is located in Valadares Island and the other is in an area located in Pontal do Sul. The results showed that even though the geological features are similar and approximately $17 \mathrm{~km}$, apart the hydrogeological results show considerable variations. The Valadares Island, displayed the effects of the tidal in the groundwater level influences the quality of water and the underground flux which not observed in Pontal do Sul. The hydraulic conductivity variation is close to $102 \mathrm{~cm} / \mathrm{s}$. The electric conductivity in Pontal do Sul is considerably lower than Valadares Island, indicating an unconfined aquifer of continental origin and without influence of tidal. The recharge in both areas are mainly related to rainfall. The discharge in Valadares Island is related to the wells that serve the population in the form of supply while in the study of the Pontal do Sul the discharge flows into the Perêque river and its mangrove area in a very narrow and near the beach.
\end{abstract}

Key-words: hydrogeology, Pontal do Sul, Ilha dos Valadares

\section{Introdução}

As áreas de estudo estão localizadas na mesma feição geológica, ou seja, estruturas sedimentares do Quaternário Holoceno. Localmente as áreas de Pontal do Sul e Ilha dos Valadares distam, em linha reta, aproximadamente $17 \mathrm{~km}$.
A ilha limita-se no extremo SW pela confluência dos rios Itiberê e dos Correas e no extremo NE, pelo canal da Cotinga. A área de estudo em Pontal do Sul é limitada pelo mar à leste e pelo rio Perequê e áreas alagadas à oeste. $A$ figura 1 apresenta a localização das áreas estudadas. 


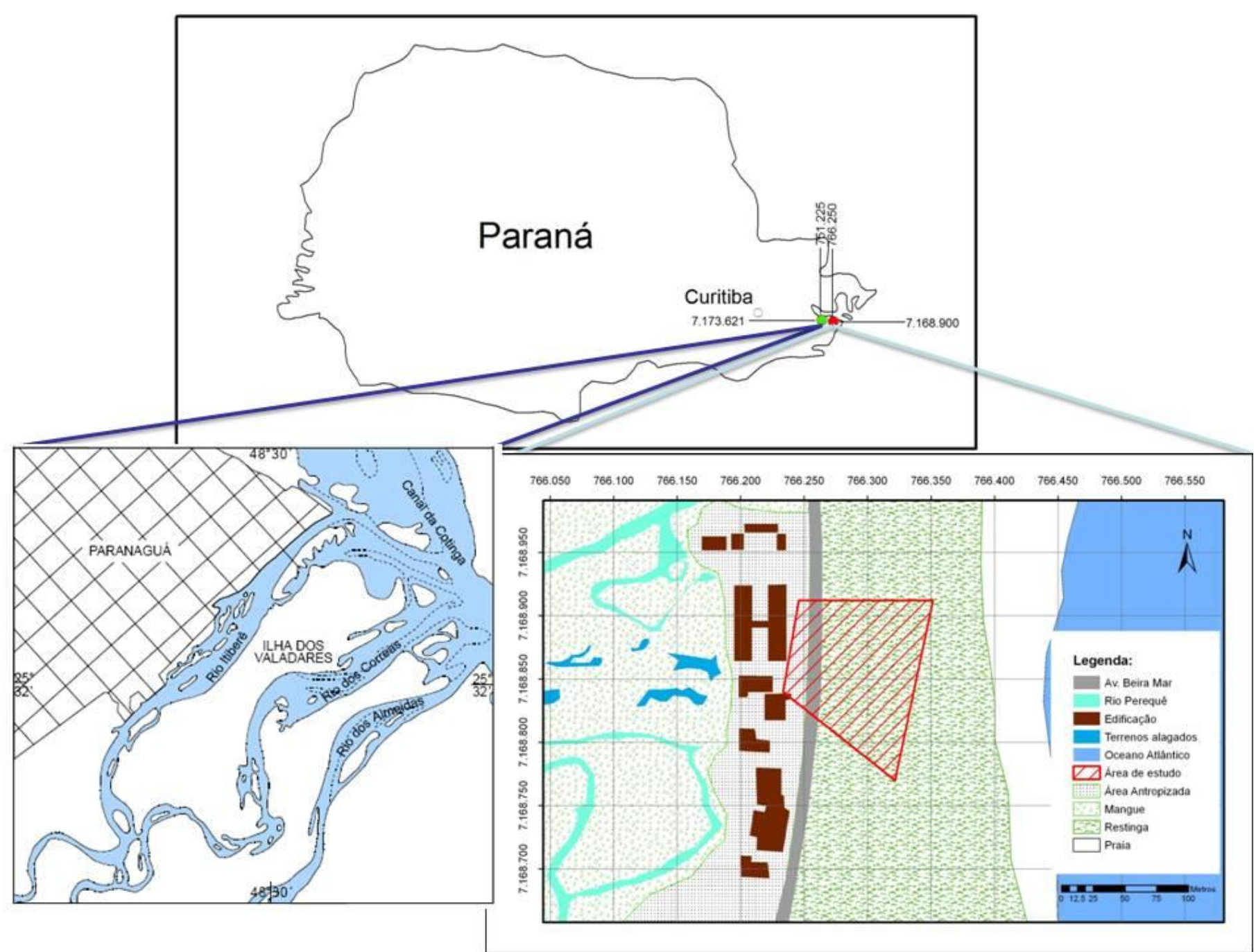

Figura 1 - Localização das áreas estudadas. Para os estudos na llha dos Valadares foram utilizados 12 (doze) poços. Em Pontal do Sul foram utilizados 5 (cinco) piezômetros e 3 (três) poços de monitoramento.

\section{Objetivos}

O objetivo desse estudo é demonstrar através de análise comparativa, por meio dos dados geológicos e hidrogeológicos entre dois estudos distintos, que mesmo pertencendo a mesma feição geológica e com pequena distância entre as áreas o quanto é complexo o estudo envolvendo a hidrogeologia costeira.

\section{Geologia local}

A Ilha dos Valadares é constituída geologicamente por sedimentos marinhos de planície costeira indiferenciados, com cordões litorâneos (MINEROPAR, Folha de Curitiba $1: 250.000,2006)$. Possui duas feições distintas: uma permanente emersa e outra periodicamente inundada pelas marés altas, formando as áreas de mangue e baixios marginais. A parte emersa é constituída, do topo para base, por areias eólicas inconsolidades, bem selecionadas, com granulometria fina a muito fina, sem estruturas sedimentares aparentes seguidas por areias finas a medias, depositadas em ambiente subaquático, (planície de maré), com estruturas sedimentares do tipo cruzada plano paralela, "estruturas de acomodação" e bioturbações. Nas margens dos rios Itiberê e dos Correas os afloramentos desse pacote atingem cerca de $6 \mathrm{~m}$ de altura. Esse pacote arenoso assenta-se discordantemente sobre as rochas do embasamento cristalino (HINDI et al., 2003). Em Pontal do Sul a geologia é constituida por sedimentos marinhos de planície costeira, indiferenciados, com cordões litorâneo da fase antiga e aluviões recentes do Quaternário Holoceno (MINEROPAR, Folha de Curitiba 1:250.000, 2006).

Os sedimentos recentes, do Cenozóico, com idades inferiores a 1,8 milhões de anos, recobrem parcialmente as rochas da Bacia do Paraná e do Escudo do Paraná. São originados por erosão e deposição dos produtos do intemperismo de litologias mais antigas.

Os sedimentos na área de Pontal do Sul, de uma maneira geral, são grãos de granulação de fina a média, constituídos basicamente de quartzo e pouca ou quase nenhuma presença de bioclastos (SOUZA, 2010). Esses sedimentos estão relacionados ao movimento de transgressão e regressão marinha, predominantemente e é 
composta por solos de textura essencialmente arenosa (RACHWAL; CURCIO, 2001).

O processo formador é hidráulico-deposicional, fluvial no interior do continente, condicionado às calhas de drenagem dos rios e planícies de inundação, e marinho e deltaico na faixa litorânea. Depósitos de terraço aluvionares mais antigos passam, com o avanço do processo erosivo, a constituírem paleoterraços em posição topográfica superior aos aluviões mais recentes. Depósitos coluviais ocorrem localmente em encostas e são provenientes de movimentos de massas. Sua formação teve início no período Quaternário e permanece ocorrendo devido ao avanço do intemperismo, erosão e retrabalhamento dos sedimentos e rochas preexistentes (MINEROPAR, 1999). Na figura 2 é apresentado a geologia recorrente em cada uma das localidades citadas.

\section{Hidrogeologia local e influência de maré}

Em toda a extensão da Ilha dos Valadares, a camada de areia superficial apresenta-se pedogeneizada, com teores variados de matéria orgânica. A uniformidade litológica da seqüência arenosa que forma o arcabouço do aqüífero confere a ele, características hidrogeológicas homogêneas e isotrópicas.

O modelo conceitual do sistema aqüífero da llha dos Valadares é o de um aqüífero livre, homogêneo e isotrópico, limitado por fronteiras móveis, definidas pela superfície potenciométrica e pela interface água doce água salgada e por uma fronteira fixa, representada pelo embasamento cristalino sobre o qual se assenta o aqüífero. A recarga do aqüífero se deve, essencialmente, às precipitações pluviométricas e a descarga ocorre através dos poços domésticos e, principalmente, ao longo das margens da ilha, diretamente para os corpos de água circundantes, conforme se verificou através de medidas de condutividade que mostram valores mais baixos junto às margens do que as medidas realizadas em direção ao eixo do rio. Outro fato que corrobora essa afirmação são as diferenças significativas entre os valores dos parâmetros físico-químicos determinados em amostras de água de poços da ilha

A potenciometria do aquífero é afetada tanto pela oscilação do nível da água causado pelas marés, como pela recarga por águas de chuva. A influência das oscilações dos níveis dos rios Itiberê e dos Correias, devido ao regime de

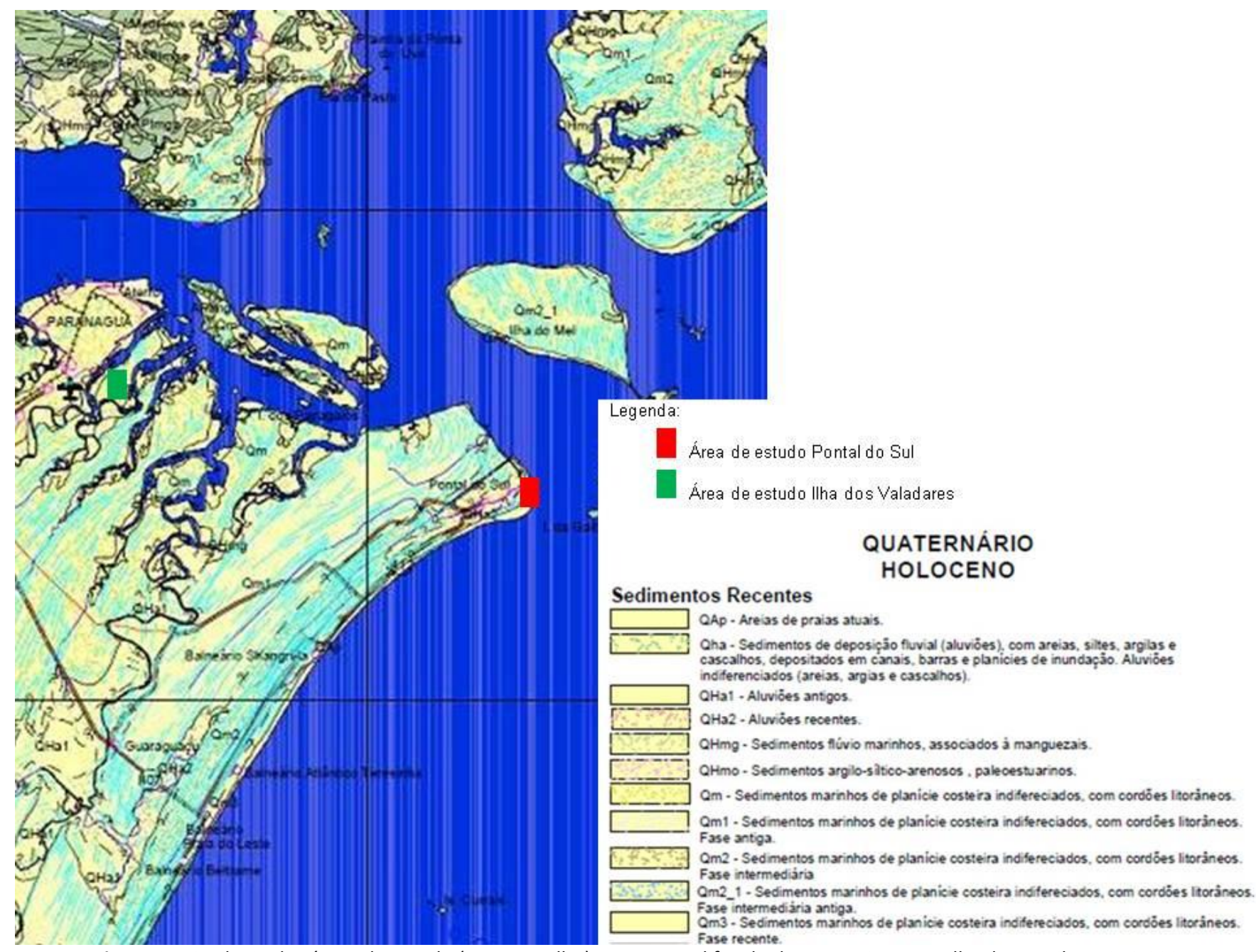

Figura 2 - Geologia das áreas de estudo (em vermelho). Fonte: Modificado de MINEROPAR - Folha de Curitiba 1:250.000. 
marés oceânicas, no aqüífero foram investigadas através da medida de nível d'água N.A. em dois poço: um situado no extremo NE da ilha, a $30 \mathrm{~m}$ da margem do rio Itiberê e outro situado na metade SW da ilha, a distâncias aproximadamente iguais de ambas das margens. Para a elaboração do mapa potenciométrico do aqüífero da llha dos Valadares, figura 3, tomou-se a precaução de fazer as medidas de nível estático no período de pouca chuva e em intervalos de tempo semelhantes, entre 13 e $17 \mathrm{~h}$ correspondente à maré baixa. Foram feitas medidas em 50 poços, entre os dias 25 e 29/06/2001. A potenciometria da ilha mostra um divisor de águas subterrâneas coincide com as maiores elevações da ilha (HINDI et al., 2003).

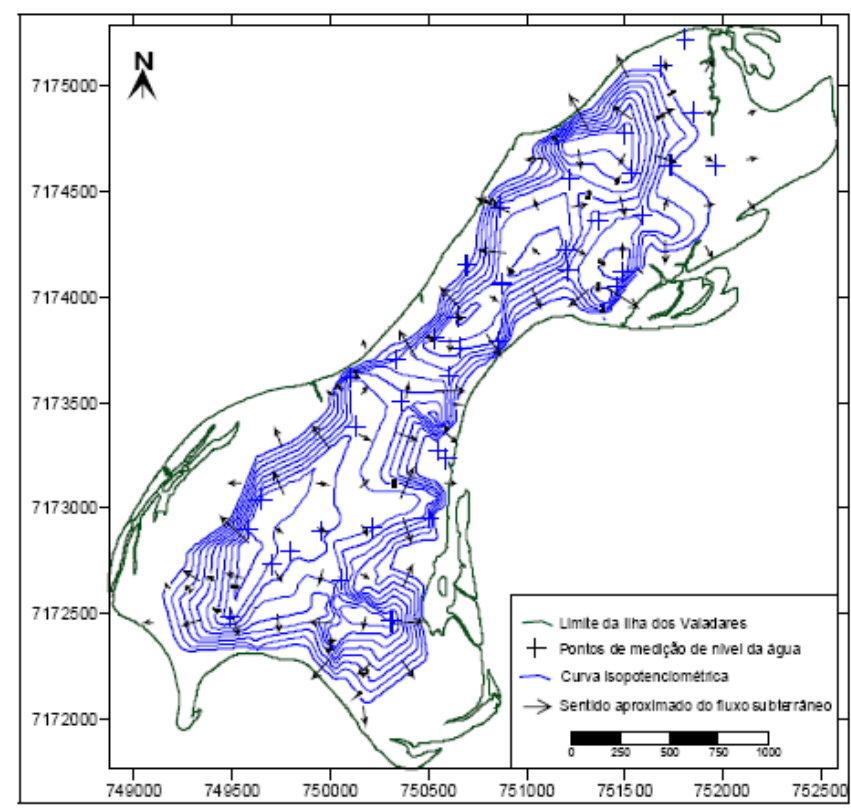

Figura 3 - Mapa potenciométrico mostrando o fluxo da água subterrânea da llha dos Valadares em 25.06.2001 e 29/06/2001.
Ressalta-se que as medidas foram realizadas durante a maré baixa. Fonte: HINDI et al., 2003.

Pontal do Sul apresenta um aqüífero livre poroso, altamente vulnerável devido a sua formação aqüífera freática ser composta estritamente de areia fina a média com elevada porosidade total e efetiva e, como resultado, apresenta elevada taxa de infiltração (SOUZA, 2010).

Entre dezembro de 2001 e julho de 2002 foram instalados 3 poços na área de estudo em Pontal do Sul (dentro da área pertencente ao Centro de Estudos do MarCEM).

As leituras observadas nos poços mediram múltiplos parâmetros durante 24 horas, em intervalos de tempo de 5 minutos. Para tanto, foi utilizado um CTD Data Logger, que foram instalados nesses poços. O monitoramento nesses poços mostraram que o nível d'água apresentou uma elevação máxima de $10 \mathrm{~cm}$ para um carregamento de maré equivalente a $1,25 \mathrm{~m}$ de amplitude, próximo à desembocadura do rio Perequê. As leituras de mudança de estágio do rio durante o período correspondente foi de $0,55 \mathrm{~m}$ a $1,5 \mathrm{~m}$, conforme registrado no CEM. O efeito da variação da água de superfície no rio Perequê e suas cercanias devido à força da maré induz uma condição de estresse ao componente água subterrânea. A distância lateral entre o estágio do rio e o poço onde foi realizado o teste de slug é de aproximadamente 50 m (SURESH BABU, 2008). A intensidade da carga de maré para dentro do rio Pereque é $0,00009 \mathrm{~m} / \mathrm{s}$ (MARONE et al., 2005). O efeito da mudança da superfície d'água dentro do canal do rio Perequê e nas vizinhanças é devido à condição de tensão induzida pela força da maré na componente da água subterrânea. Esquematicamente, está apresentado na figura 4 a intensidade do carregamento da maré na área em Pontal do Sul.

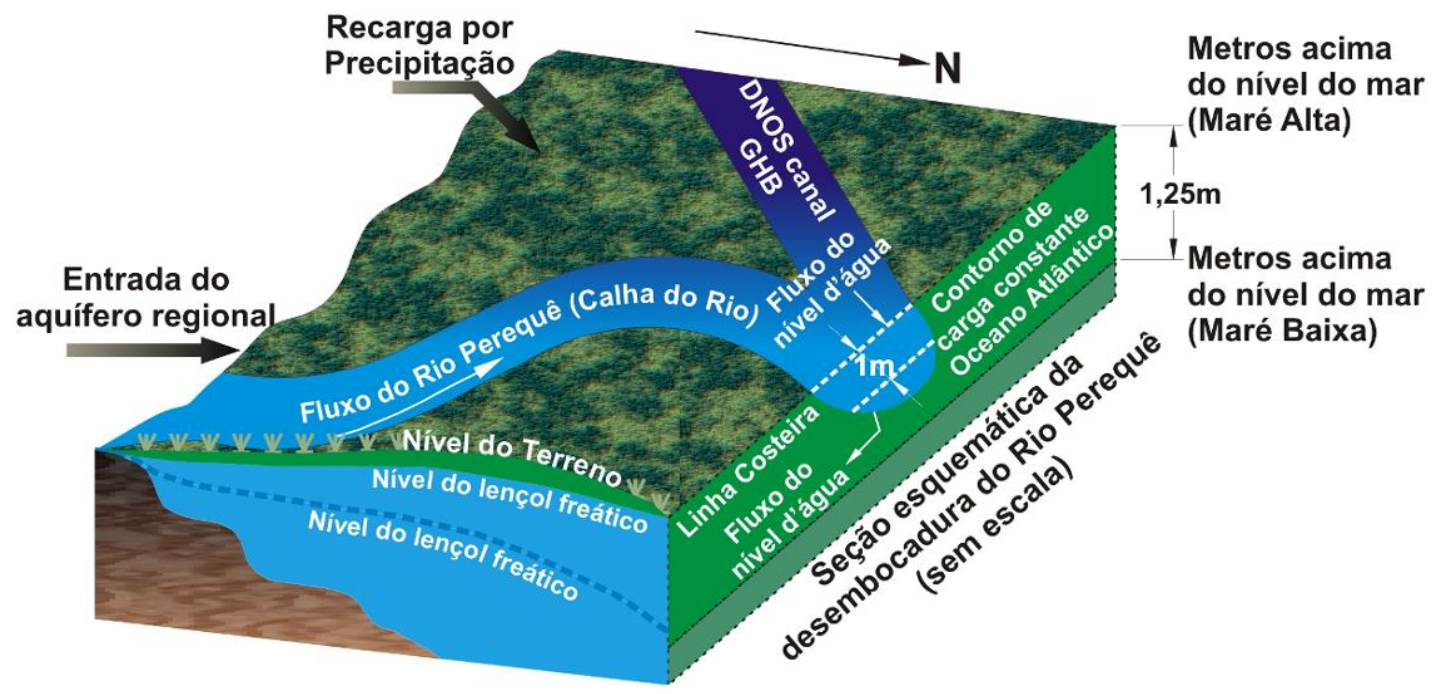

Figura 4 - Modelo Conceitual da zona do aquífero em Pontal do Sul. Fonte: Adaptado de SURESH BABU et al., 2008. 
Se na llha dos Valadares a potenciometria é afetada pela influência das marés oceânias e pelos corpos d'água que circundam a ilha, em Pontal do Sul não é verificado esse fenômeno. Porém, ao se fazer as primeiras leituras nível d'água em 25.04.2009 e no dia 26.04.2009, no intervalo de 14:40 hs a 15:45 hs, a primeira hipótese foi de que a maré era o fator predominante no fluxo. Analisando os dados da tábua de maré da Diretoria de Hidrografia e Navegação da Marinha do Brasil, estação de Barra de Paranaguá - Canal da Galheta, verificou-se que as medições de nível d'água coincidiram com as maiores elevações de maré nos dias dos experimentos (25.04.2009, 15:49 hs, altura: $1,60 \mathrm{~m}$ e 26.04.2009, 16:30 hs, altura: 1,50 m), conforme é apresentado na figura 5 . Vale ressaltar que o nível médio de maré para esta estação é de 0,79 $\mathrm{m}$.

Levando-se em consideração apenas a hipótese de que a maré influenciaria a inversão do fluxo subterrâneo (para o continente), em 05.10.2009, foram realizados dois experimentos considerando o nível mais baixo da maré (0,10 m de altura, por volta de 09:00 hs) e o nível mais alto (1,50 m, por volta de 15:38 hs) como é mostrado nas figuras 5 e 6 .

Com o objetivo de se compreender o comportamento hidrogeológico da área de estudo, em Pontal do SUL, principalmente quanto ao comportamento do fluxo subterrâneo, optou-se por um monitoramento sistemático durante um período de trinta e quatro dias corridos, durante 24 horas com medições de cinco em cinco minutos, utilizando um Mini-Diver ${ }^{\circledR}$ Modelo DI 501 e interpretados através do software Diver-Office $2008^{\circledR}$. Necessitou-se utilizar um outro equipamento para se fazer a compensação barométrica do nível dágua por meio de um equipamento denominado Baro-Diver ${ }^{\circledR}$.

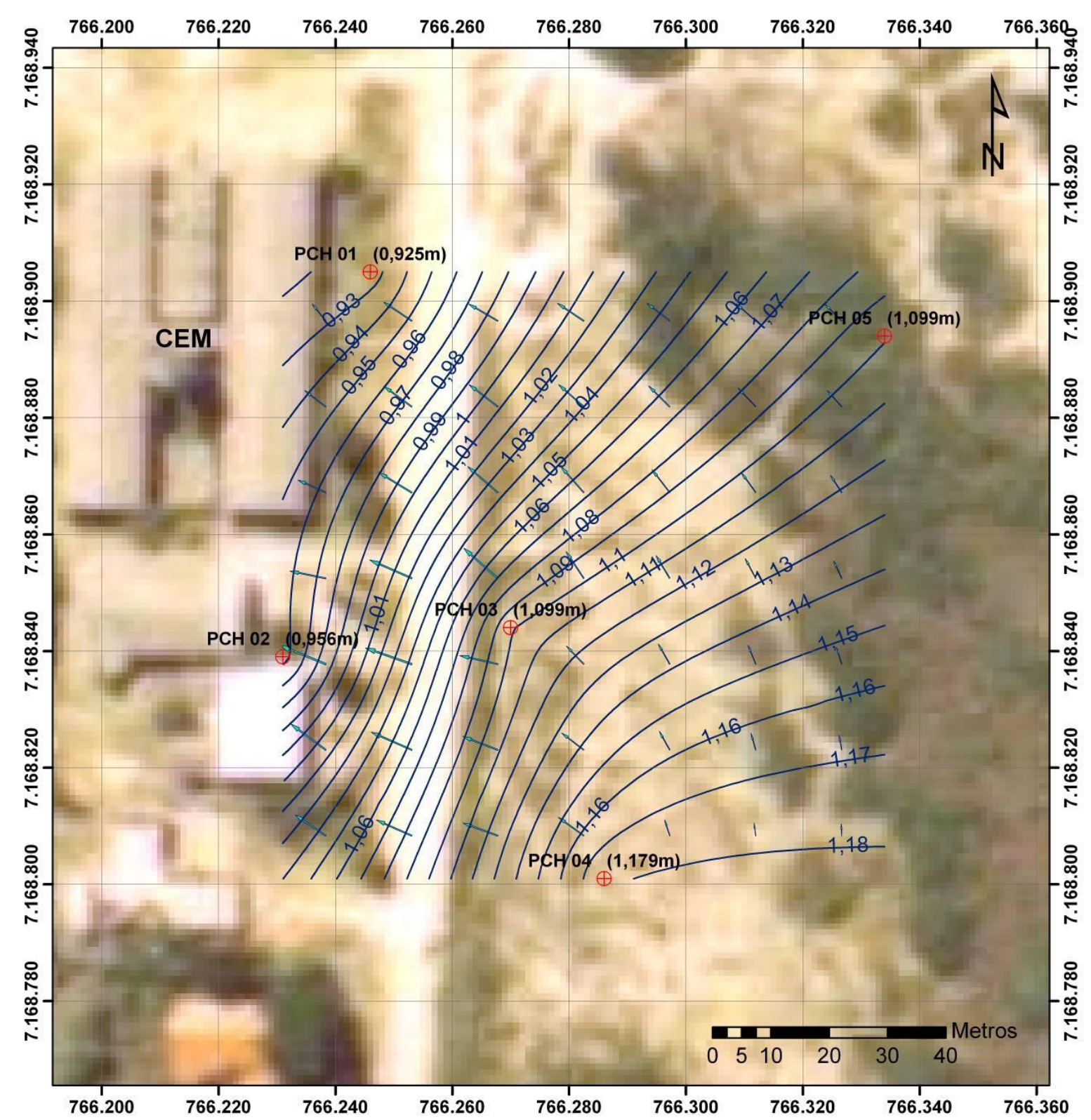

Figura 5 - Mapa potenciométrico mostrando o fluxo da água subterrânea da área de estudo em Pontal do Sul em 05.10.2009 por volta das 09:00 hs. Maré baixa 0,10 $\mathrm{m}$ de altura. 


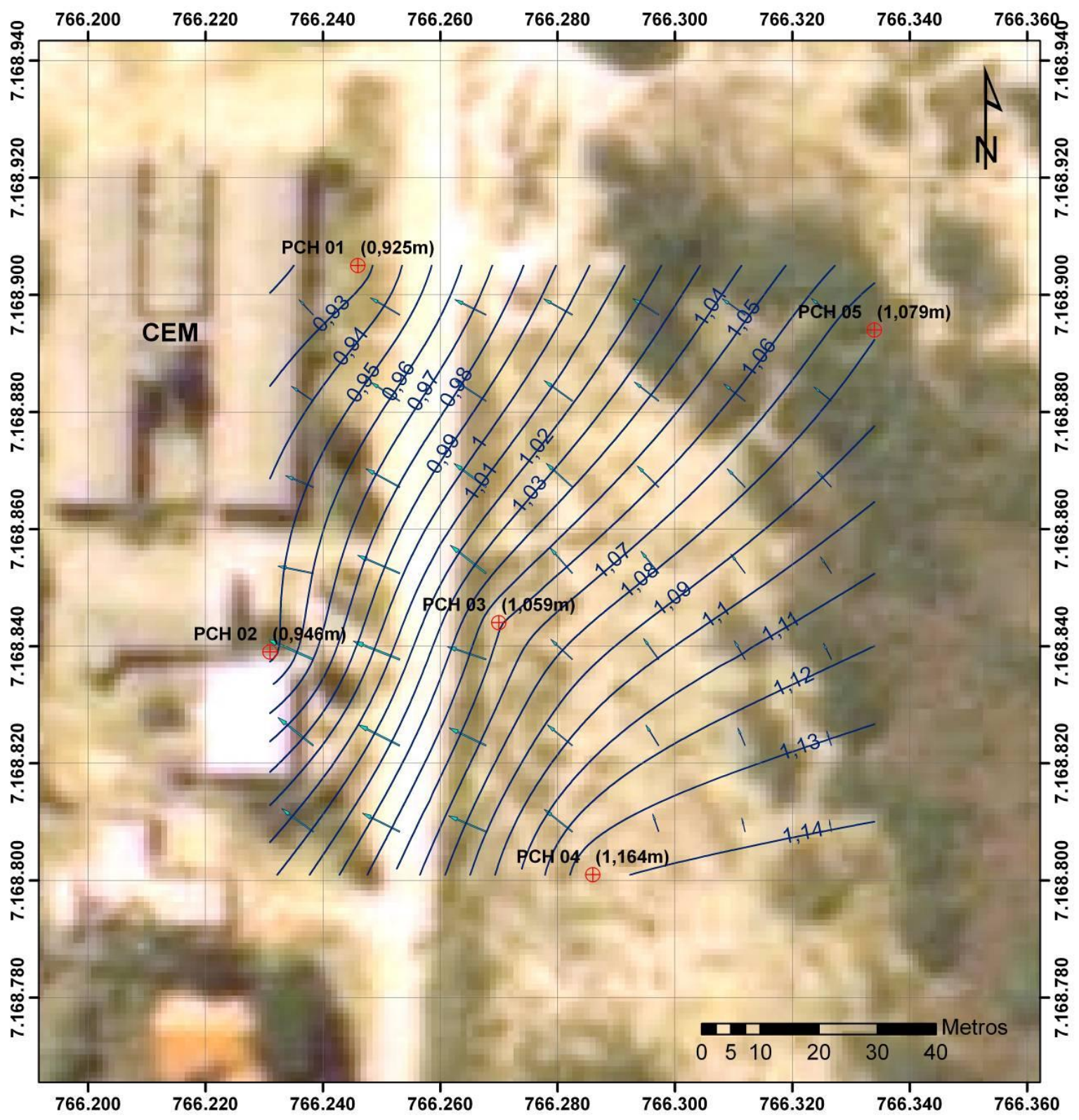

Figura 6 - Mapa potenciométrico mostrando o fluxo da água subterrânea da área de estudo em Pontal do Sul em 05.10 .2009 por volta das 15:38 hs. Maré alta $1,50 \mathrm{~m}$ de altura.

O período abrangeu todas as fases da Lua e foi comparado com os dados da tábua de marés obtido junto à Diretoria de Hidrografia e Navegação da Marinha do Brasil, estação de Barra de Paranaguá - Canal da Galheta, entre os dias 06.10.2009 a 09.11.2009.

Os dados obtidos mostraram resultados que podem explicar parte do fenômeno que ocorre na área estudada em Pontal do Sul, conforme é mostrado na figura 7.

Os dados demonstram que a maré tem pouco ou quase nenhuma influência na variação do N.A. Os picos de elevação do N.A. coincidem com os picos de chuva. Isso pode ser explicado pelo fato de a geologia do aqüífero livre ser formada exclusivamente de areia de granulação fina a média com elevada porosidade efetiva. Isso corrobora para que a água de chuva, ao chegar ao solo, seja quase imediatamente infiltrada, recarregando o aqǘfero $e$ refletindo dessa forma na elevação do N.A. (SOUZA, 2010).

\subsection{Qualidade das águas}

As amostras de água subterrânea para fins de abastecimento público na Ilha dos Valadares, parâmetros físico-químicos e bacteriológicos, foram realizadas em 12 poços-ponteira utilizados no abastecimento de residências. Esses pontos estão distribuídos em toda ilha, de modo a caracterizar a influência de distintos ambientes na hidroquímica do aqüifero. As análises foram realizadas no Laboratório de Pesquisas Hidrogeológicas-LPH (Departamento de Geologia/UFPR), com a determinação dos principais cátions e ânions. Os parâmetros $\mathrm{pH}$, condutividade elétrica e temperatura foram medidos no momento da coleta das amostras (tabela 1).

As espécies $\mathrm{Na}+, \mathrm{Cl}_{-}$, e $\mathrm{SO}_{4} 2-$, apresentaram boa correlação linear positiva entre si, indicando origem comum 


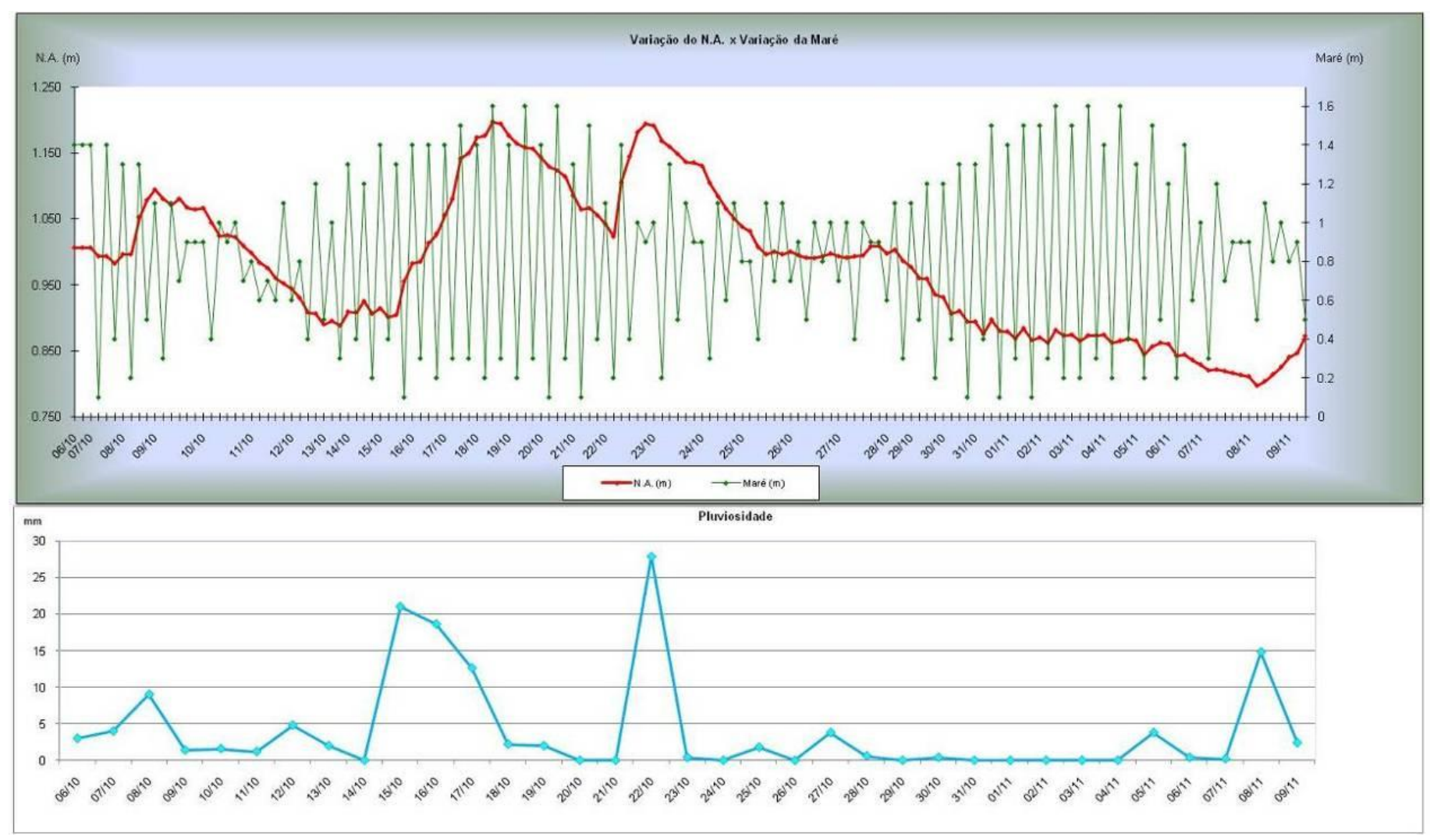

Figura 7 - Gráfico variação do N.A.do piezômetro PCH 01 x variação da maré.

Tabela 1 - Resultados das análises físico-químicas de água coletada na Ilha dos Valadares.

\begin{tabular}{|c|c|c|c|c|c|c|c|c|c|c|c|c|c|}
\hline \multirow{2}{*}{ Parâmetro } & \multicolumn{13}{|c|}{ Amostra } \\
\hline & 1 & 2 & 3 & 4 & 5 & 6 & 7 & 8 & 9 & 10 & 11 & 12 & rio \\
\hline Temperatura $^{1}$ & 22.8 & 23.9 & 24.4 & 24.6 & 25.1 & 26.2 & 27.8 & 24.4 & 24.5 & 27.1 & 23.7 & 23.4 & 28.0 \\
\hline Condutividade $^{2}$ & $249^{2}$ & ${ }_{2}^{105}$ & $144^{2}$ & $77^{2}$ & $202^{2}$ & $70^{2}$ & $165^{2}$ & $70^{2}$ & $72^{2}$ & $57^{2}$ & $47^{2}$ & $25^{2}$ & $41^{\circ}$ \\
\hline $\mathrm{PH}$ & 5.26 & 5.11 & 5.55 & 5.30 & 3.76 & 4.42 & 4.47 & 4.50 & 4.11 & 5.36 & 5.09 & 4.65 & 7.50 \\
\hline $\begin{array}{l}\text { N-Kjendal } \\
\text { Total }\end{array}$ & 1.56 & 0.25 & 0.33 & 0.85 & 0.14 & 0.07 & 0.35 & 1.17 & 0.45 & 0.48 & 0.11 & $<0.01$ & 0.60 \\
\hline N-Amoniacal & 1.48 & $<\mathrm{LD}$ & 0.04 & 0.64 & $<0.01$ & $<0.01$ & 0.03 & $<0.01$ & 0.05 & 0.20 & $<0.01$ & $<0.01$ & 0.60 \\
\hline N-Orgânico & 0.08 & 0.25 & 0.29 & 0.21 & 0.14 & 0.07 & 0.32 & 1.17 & 0.40 & 0.28 & 0.11 & $<0.01$ & $<0.01$ \\
\hline Alcalin. Total $^{3}$ & 4.8 & 1.9 & 3.30 & 4.50 & 5.10 & 3.50 & 2.00 & 2.80 & 4.20 & 13.40 & 3.60 & 2.60 & 95.3 \\
\hline Dureza Total & 12.11 & 5.16 & 13.32 & 4.09 & 13.93 & 8.59 & 7.82 & 9.72 & 6.99 & 9.64 & 8.06 & 3.64 & 3894 \\
\hline $\mathrm{SDT}^{4}$ & 182 & 82 & 110 & 58 & 151 & 50 & 125 & 52 & 54 & 42 & 33 & 19 & 23477 \\
\hline $\mathrm{SiO}_{2}$ & 12.52 & 11.2 & 8.16 & 13.04 & 6.40 & 4.44 & 10.48 & 5.81 & 9.00 & 10.23 & 5.19 & 8.77 & 1.50 \\
\hline $\mathrm{HCO}_{3}^{-}$ & 5.86 & 2.32 & 4.03 & 5.49 & 6.22 & 4.27 & 2.44 & 3.42 & 5.12 & 16.30 & 4.39 & 3.17 & 116 \\
\hline $\mathrm{Cl}^{-}$ & 56.5 & 30.2 & 18.5 & 13.9 & 21.9 & 14.7 & 42.1 & 6.4 & 19.7 & 9.7 & 5.1 & 5.2 & 15229 \\
\hline $\mathrm{F}^{-}$ & 0.13 & 0.03 & $<0.01$ & 0.10 & $<0.01$ & $<0.01$ & 0.06 & 0.08 & 0.05 & 0.09 & $<0.01$ & $<0.01$ & 1.78 \\
\hline $\mathrm{PO}_{4}^{-3}$ & 0.19 & 0.06 & $<0.03$ & $<0.03$ & $<0.03$ & $<0.03$ & $<0.03$ & 0.38 & 0.04 & $<0.03$ & $<0.03$ & 0.06 & 0.14 \\
\hline $\mathrm{SO}_{4}^{-2}$ & 32.5 & 4.2 & 28.0 & 0.5 & 15.0 & 0.5 & 13.0 & 2.0 & 2.9 & 0.5 & 2.3 & 0.5 & 1732 \\
\hline $\mathrm{NO}_{3}^{-}$ & 0.02 & 0.97 & 0.02 & 0.02 & 32.70 & 7.65 & 1.41 & 7.47 & 0.62 & 0.04 & 7.96 & 2.05 & 0.04 \\
\hline $\mathrm{NO}_{2}^{-}$ & $<\mathrm{LD}^{5}$ & $<\mathrm{LD}^{5}$ & $<\mathrm{LD}^{5}$ & $<\mathrm{LD}^{5}$ & $<\mathrm{LD}^{5}$ & $<\mathrm{LD}^{5}$ & $<\mathrm{LD}^{5}$ & $<\mathrm{LD}^{5}$ & $<\mathrm{LD}^{5}$ & $<\mathrm{LD}^{5}$ & $<\mathrm{LD}^{5}$ & $<\mathrm{LD}^{5}$ & $<\mathrm{LD}^{5}$ \\
\hline $\mathrm{Ca}^{+2}$ & 1.59 & 0.88 & 1.82 & 1.06 & 3.17 & 2.27 & 1.68 & 2.64 & 1.66 & 2.41 & 2.04 & 0.93 & 345 \\
\hline $\mathrm{Mg}^{+2}$ & 1.98 & 0.72 & 1.89 & 0.35 & 1.46 & 0.71 & 0.88 & 0.76 & 0.69 & 0.88 & 0.72 & 0.32 & 738 \\
\hline $\mathrm{Na}^{+}$ & 44.0 & 14.7 & 22.5 & 8.1 & 27.5 & 8.4 & 27.0 & 3.2 & 9.8 & 5.4 & 2.8 & 2.5 & 8100 \\
\hline $\mathrm{K}^{+}$ & 5.25 & 3.15 & 2.60 & 3.10 & 5.65 & 1.05 & 2.85 & 5.00 & 2.40 & 1.65 & 1.95 & 1.05 & 162 \\
\hline Fe Total & 6.51 & 0.24 & 1.09 & 0.71 & 0.01 & 0.15 & 0.14 & 0.25 & 2.30 & 0.74 & 0.01 & 0.18 & 0.33 \\
\hline Colif. Totais & Pres. & Aus. & Pres. & Pres. & Pres. & Pres. & Pres. & Pres. & Pres. & Pres. & Pres. & Pres. & -- \\
\hline Colif. Fecais & Pres. & Aus. & Aus. & Pres. & Pres. & Pres. & Pres. & Aus. & Aus. & Aus. & Pres. & Pres. & -- \\
\hline
\end{tabular}

$\begin{array}{llll}{ }^{1} \text { Temperatura } \mathrm{em}^{\circ} \mathrm{C} & { }^{5} \mathrm{LD}=0,006 & \\ 2 & & \end{array}$

${ }^{3}$ Alcalinidade total em $\mathrm{mg} / \mathrm{L}$ de $\mathrm{CaCO}_{3}$

${ }^{4}$ Sólidos Dissolvidos Totais 


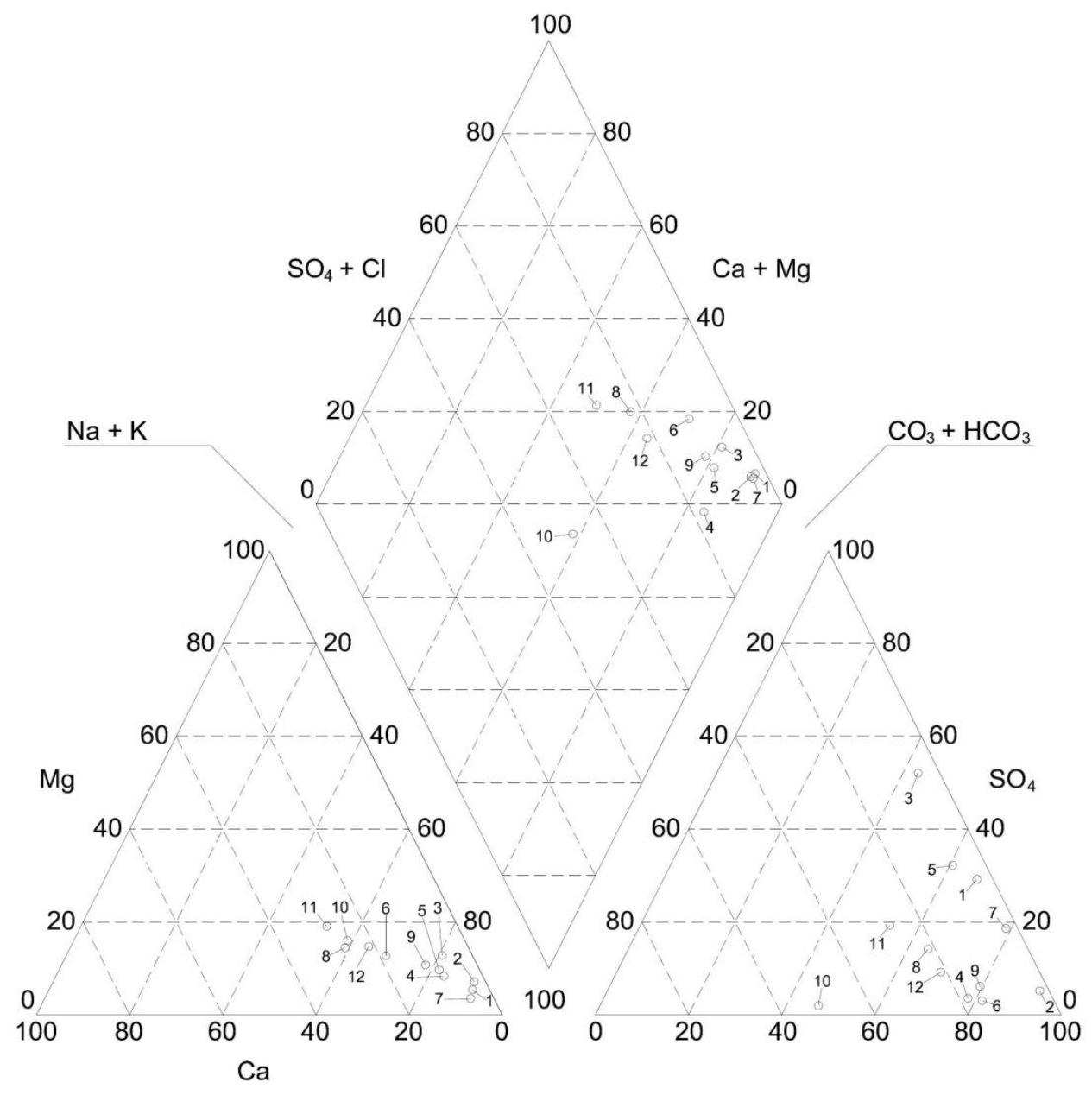

Figura 8 - Diagrama de Piper mostrando a classificação da água coletada na llha dos Valadares.

e associada à água do mar, já que são espécies aí predominante.

As amostras coletadas na porção SW da ilha, apresentam os valores de relação iônica $\mathrm{rHCO}-/ \mathrm{rCl}-\mathrm{e}$ $(\mathrm{rCa}+2+\mathrm{rMg}+2) / \mathrm{rCl}$ - mais elevado que o das outras amostras. Outro aspecto diferencial dessas amostras, é o fato das concentrações dos íons $\mathrm{Cl}$-, $\mathrm{SO} 4$ 2- e $\mathrm{Na}+$, estarem abaixo dos valores obtidos para os mesmos íons nas demais amostras. Esses dados caracterizam águas menos sujeitas a influências das águas marinhas, seja sob a forma de aerosóis ou contaminação por cunha salina.

As amostras coletadas na ilha, são em geral, segundo a classificação geoquímica de Piper do tipo cloretada-sódica, conforme é apresentado na figura 8.

No entanto, em função da distância entre os pontos de coleta e as margens da ilha, outras espécies iônicas contribuem para uma diferenciação dos tipos geoquímicos das amostras coletadas.

As amostras de água apresentam caráter ácido, com pH variando de 3,76 a 5,5, provavelmente em conseqüência da matéria orgânica presente nos horizontes mais superficiais do pacote arenoso. O teor de sólidos dissolvidos totais, considerando o ambiente estuarino, é relativamente baixo, variando de 19 a $182 \mathrm{mg} / \mathrm{L}$. A temperatura média da água é de 24,82 OC e de condutividade elétrica média de 106,91 $\mu \mathrm{S} / \mathrm{cm}$. (HINDI et al., 2003).

Em Pontal do Sul a água segundo Custódio e Llamas (2001) (tabela 2), por meio das relações iônicas $\mathrm{rMg}+2 / \mathrm{rCa}+2, \mathrm{rCl}-/ \mathrm{rHCO} 3-$ e $\mathrm{rSO} 42-/ \mathrm{rCl}$ - indicam uma origem continental para as águas da área de estudo (tabela 3).

Tabela 2 - Relação iônica segundo Custódio e Llamas, 2001.

\begin{tabular}{cc}
\hline \multicolumn{2}{c}{ Relação iônica } \\
\hline $\mathrm{rMg} / \mathrm{Ca}$ & 0,33 \\
\hline $\mathrm{rSO}_{4} / \mathrm{rCl}$ & 0,19 \\
\hline $\mathrm{rCl} / \mathrm{rHCO}_{3}$ & 0,23 \\
\hline
\end{tabular}

Segundo a classificação geoquímica de Piper, a água da área de estudo em Pontal do Sul é essencialmente bicarbonatada cálcica-sódica, conforme é apresentado na figura 9.

Os demais parâmetros apresentados na Tabela 4, foram medidos in situ e apresentam temperatura média de 27,1 oC em períodos de menor índice de pluviosidade e condutividade elétrica média de $187,25 \mu \mathrm{S} / \mathrm{cm}$. 
Tabela 3 - Resultados das análises físico-químicas de água coletada na área de estudo em Pontal do Sul.

\begin{tabular}{|c|c|}
\hline Parâmetro & Resultado (mg/L) \\
\hline Alcalinidade total & 23,31 \\
\hline Alcalinidade à fenolftaleína & 0,00 \\
\hline Dureza total & 22,60 \\
\hline Acidez & 18,30 \\
\hline Dióxido de carbono livre & 16,10 \\
\hline Nitrogênio Kjeldahl total & 0,13 \\
\hline Nitrogênio amoniacal & 0,10 \\
\hline Nitrogênio orgânico & 0,03 \\
\hline Sólidos totais a $103^{\circ} \mathrm{C}$ & 42,00 \\
\hline Sólidos suspensos totais & $<5,00$ \\
\hline Sólidos dissolvidos totais & 42,00 \\
\hline Sílica dissolvida & 7,10 \\
\hline DQO - Demanda química de & 43,00 \\
\hline Bicarbonato & 28,44 \\
\hline Carbonato & 0,00 \\
\hline Hidróxido & 0,00 \\
\hline Cloreto & 3,87 \\
\hline Fluoreto & $<0,01$ \\
\hline Fosfato & 0,18 \\
\hline Sulfato & $<1,00$ \\
\hline Nitrato & $<0,04$ \\
\hline Nitrito & $<0,01$ \\
\hline Cálcio & 6,82 \\
\hline Magnésio & 1,36 \\
\hline Sódio & 5,60 \\
\hline Potássio & 0,20 \\
\hline Ferro total & 3,16 \\
\hline Ferro III & 2,89 \\
\hline Ferro II & 0,27 \\
\hline Manganês & 0,05 \\
\hline
\end{tabular}

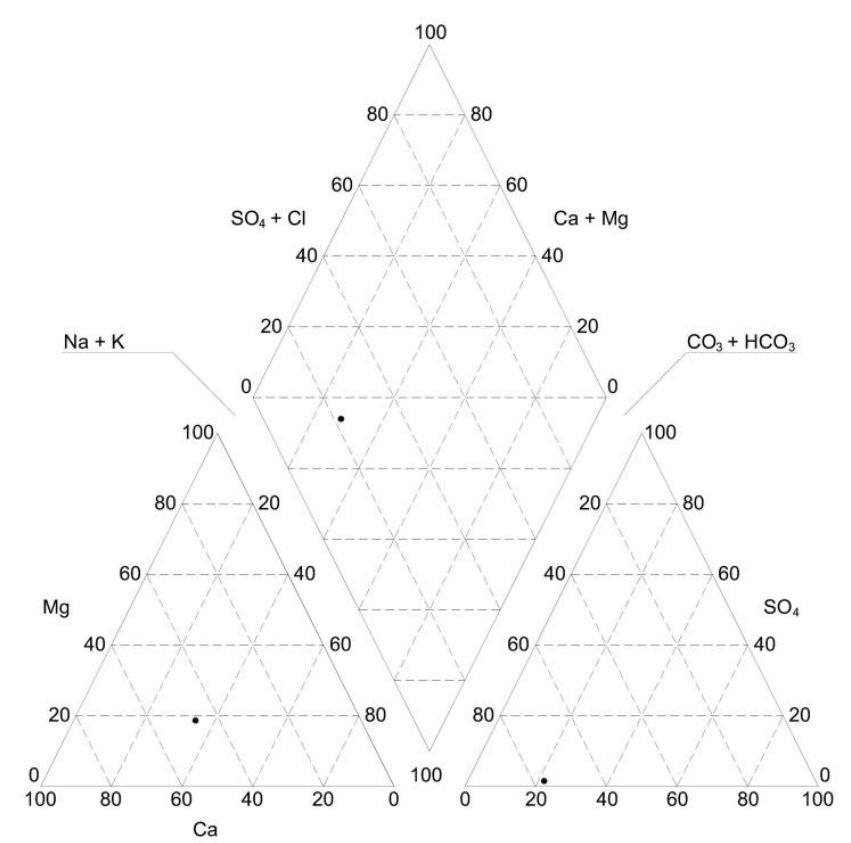

Figura 9 - Diagrama de Piper mostrando a classificação da água coletada na área de estudo em Pontal do Sul.
Tabela 4 - Resultados das análises de água medidos in situ em Pontal do Sul.

\begin{tabular}{ccccc}
\hline $\begin{array}{c}\text { Parâmetro } \\
\text { Analisado }\end{array}$ & PCH 01 & PCH 02 & PCH 04 & PCH 05 \\
\hline C.E. $(\mu \mathrm{s} / \mathrm{cm})$ & 159 & 150 & 117 & 323 \\
\hline Eh $(\mathrm{mV})$ & 97 & 89 & 23 & 84 \\
\hline $\begin{array}{c}\text { Temperatura } \\
\left({ }^{\circ} \mathrm{C}\right)\end{array}$ & 27,6 & 26,2 & 26,9 & 27,7 \\
\hline $\mathrm{pH}$ & 6,95 & 6,15 & 7,95 & 6,8 \\
\hline
\end{tabular}

De acordo com os dados da Tabela 4, as águas amostradas em Pontal do Sul caracterizam-se por apresentarem baixa mineralização, com condutividade elétrica inferior a $350 \mu \mathrm{s} / \mathrm{cm}$. O Eh encontra-se normalmente acima de $80 \mathrm{mV}$, sugerindo assim um ambiente oxidante, embora na amostra do $\mathrm{PCH} 04$ este valor esteja próximo de $20 \mathrm{mV}$, indicando uma tendência redutora para o ambiente. No que diz respeito ao $\mathrm{pH}$, todas as amostras apresentaram caráter neutro, sendo que apenas a amostra $\mathrm{PCH} 04$ destacou-se das demais, com $\mathrm{pH}$ levemente básico.

\subsection{Condutividade hidráulica}

A condutividade hidráulica, na Ilha dos Valadares, foi realizada por meio do método ensaio de bombeamento com duração de 24 horas, com bombeamento contínuo a uma taxa de 5,4 m3/h (vazão máxima da bomba). Os dados rebaixamento $x$ tempo foram analisados pelo método de Jacob utilizando-se o programa GWW - Groundwater Software for Windows. A condutividade hidráulica, em Pontal do Sul, foi realizada por meio de teste de slug e os resultados foram interpretados utilizando o software Winslug ${ }^{\circledR}$ que utiliza o método de Hvorslev para análise dos dados de rebaixamento $x$ tempo. Os testes de slug foram escolhidos por serem de rápida realização, apresentarem baixo custo e com a principal vantagem, em relação ao testes de bombeamento, de não gerar água potencialmente contaminada. Os testes forneceram os seguintes valores apresentados na tabela 5 .

Tabela 5 - Condutividade hidráulica do aqüífero da llha dos Valadares e Pontal do Sul.

\begin{tabular}{|c|c|c|c|c|c|c|c|}
\hline \multirow[t]{2}{*}{ Parâmetro } & \multicolumn{6}{|c|}{ Bateria de Poços - Ilha dos Valadares } & \multirow[t]{2}{*}{ Média } \\
\hline & 1 & 2 & 3 & 4 & 5 & 6 & \\
\hline Cond.Hidráu & 0,7 & 0,75 & 0 & 0,74 & 0,74 & 0,75 & 0,758 \\
\hline \multirow{2}{*}{ lica (cm/s) } & 67 & 2 & 78 & 1 & 7 & 9 & \\
\hline & & & 3 & & & & \\
\hline \multirow[t]{2}{*}{ Parâmetro } & \multicolumn{6}{|c|}{ Piezômetros - Pontal do Sul } & Média \\
\hline & \multicolumn{2}{|c|}{1} & & 2 & \multicolumn{2}{|r|}{3} & \\
\hline $\begin{array}{l}\text { Cond.Hidráu } \\
\text { lica }(\mathrm{cm} / \mathrm{s})\end{array}$ & \multicolumn{2}{|c|}{$3,20 \times 10^{-3}$} & \multicolumn{2}{|c|}{$2,44 \times 10^{-3}$} & \multicolumn{2}{|c|}{$7,33 \times 10^{-3}$} & $\begin{array}{r}4,32 \\
\times 10^{-3}\end{array}$ \\
\hline
\end{tabular}




\section{Conclusões}

- O divisor de águas da Ilha dos Valadares está condicionado a topografia local (maiores elevações da ilha), enquanto que o divisor de águas em Pontal do Sul está condicionado à proximidade da linha de costa, em uma pequena faixa entre os piezômetros 03, 04, 05 e a praia.

- A descarga do aqüífero livre na llha dos Valadares ocorre através dos poços domésticos e, principalmente, ao longo das margens da ilha, diretamente para os corpos de água que a circudam. Em Pontal do Sul a descarga é em sua grande parte para o rio Perequê e em menor proporção para o mar.

- A recarga do aqüífero livre e ambas regiões estão condicionadas a indices pluviométricos.

- O fluxo subterrâneo na llha dos Valadares está condicionado ao movimento de marés, enquanto que em Pontal do Sul essa influência e nenhuma ou quase nenhuma.

- A água na llha dos Valadares é em geral cloretadasódica, caracterizando que o aqüífero livre tem forte influência do movimento de marés. Já em Pontal do Sul é essencialmente bicarbonatada cálcica-sódica e é característicamente de origem continental.

- As amostras coletadas na porção SW da ilha, e demonstrados através das relações iônicas $\mathrm{rHCO}-/ \mathrm{rCl}-\mathrm{e}$ $(\mathrm{rCa}+2+\mathrm{rMg}+2) / \mathrm{rCl}$ - e o fato das concentrações dos íons $\mathrm{Cl}-$ , SO4 2- e $\mathrm{Nat}$, estarem abaixo dos valores obtidos para os mesmos íons nas demais amostras, caracterizam águas menos sujeitas a influências das águas marinhas, seja sob a forma de aerosóis ou contaminação por cunha salina. Em contrapartida, as espécies $\mathrm{Na}+, \mathrm{Cl}$-, e SO4 2- encontradas em outras partes da Ilha dos Valadares apresentaram boa correlação linear positiva entre si, indicando origem comum e associada à água do mar o que não é observado na área em Pontal do Sul.

- Na Ilha dos Valadares as amostras de água subterrânea apresentam caráter ácido, com pH variando de 3,76 a 5,5 enquanto que em Pontal do Sul apresenta caráter neutro a levemente básico. O teor de sólidos dissolvidos totais, considerando o ambiente estuarino, é relativamente baixo, variando de 19 a $182 \mathrm{mg} / \mathrm{L}$ na llha dos Valadares e em Pontal do Sul é ainda mais baixo $42,0 \mathrm{mg} / \mathrm{L}$ considerando o mesmo ambiente.

- A temperatura média da água subterrânea na Ilha dos Valadares é de 24,82 0C, enquanto que em Pontal do Sul é de 27,01 0C.

- A condutividade elétrica média na llha dos Valadares é de 106,91 $\mathrm{S} / \mathrm{cm}$. Já em Pontal do Sul é de 187,25 $\mu \mathrm{S} / \mathrm{cm}$. Apesar da água em Pontal do Sul ter origem continental o fato da média de condutividade elétrica ser maior que a da Ilha dos Valadares está relacionada a quantidade de número de pontos para realização das médias e um ponto com valor extremamente elevado (ponto mais próximo da praia) é responsável por elevar essa média.

- Apesar de ambas as áreas estarem situadas na mesma feição geológica, diferentes características são apresentadas tanto na qualidade das águas subterrâneas, fluxo subterrâneo e principalmente condutividade hidraúlica.

\section{Referências bibliográficas}

MINEROPAR - Minerais do Paraná, S.A. Geologia do Paraná. Disponível em: <http://www.mineropar.pr.gov.br/arquivos/File/MapasPDF/G eologocos/curitiba.PDF>. Acesso em: 07 fev. 2010. 17:48.

MARONE E., MANTOVANELLI A., KLINGENFUSS S.M., LAUTERT, F.C.L., PRATA JR. P.V., NOENBERG M.A. 2005. Transport of water, salt, heat and suspended particulate matter during a spring tide event at Pereque tidal creek, southern Brazil (submitted).

HINDI E.C., ROSA FILHO E.F. Da, BITTENCOURT A.V.L., XAVIER J.M. 2003. Revista Latino-Americana de Hidrogeologia, Curitiba, 3:19-31.

RACHWAL M.F.G., CURCIO, G.R. 2001. Revista Scientia Forestalis, 59: 153-163.

SOUZA R.T. 2010. Aspectos fundamentais à compreensão da hidrogeologia costeira numa área de Pontal do Sul - PR. Dissertação (Dissertação de Mestrado em Geologia). Curitiba: Departamento de Geologia, Universidade Federal do Paraná.

SURESH BABU D.S., SAHAI A.K., NOENBERG M.A., MARONE E. 2008. Hydraulic response of a tidally forced coastal aquifer, Pontal do Paraná, Brazil. Hidrogeology Journal, 16 (7): 14271439. 